\title{
The Dynamics of Balinese Lexicon in Sanur Tourism Area: An Ecolinguistic Approach
}

\author{
I Nyoman Kardana ${ }^{1}$, I Made Astu Mahayana ${ }^{1} \&$ I Gusti Ngurah Adi Rajistha ${ }^{1}$ \\ ${ }^{1}$ Warmadewa University, Bali, Indonesia \\ Correspondence: I Nyoman Kardana, Warmadewa University, Bali, Indonesia. Telp: 628-1338-516-716, E-mail: \\ ikardana@yahoo.com.
}

Received: December 14, 2020; Accepted: December 23, 2020; Published: December 24, 2020

\begin{abstract}
Ecolinguistics has been the research interest for many linguists in recent years. However, ecolinguitic researches in Indonesia are still concerned on examining the lexicon in one particular field. For this reason, this study aims to examine the lexicon treasures found in tourism area of Sanur. This is chosen as the object of this research as the tourism area is most at risk of being exposed to globalization due to tourism developments. The flow of globalization due to the development of information technology and tourism can change behavior, social attitudes or social life of the society, and the biological environment of the area as well. Based on the research results, it was found that the lexicons used by the Sanur community are not only lexicons that have a physical form or an activity, but there are also some lexicons that only refer to the concept (abstract) without finding the objects or physical activities referred to by these lexicons. The people of Sanur also feel that in the early development of tourism in the area there was still a balance between the environment and the needs of tourism.
\end{abstract}

Keywords: ecolinguistics, lexicon, social perception, biological environment, social environment, ideological environment

\section{Introduction}

Tourism in Bali has developed since the colonial era on the island. Since then many foreigners, especially the Dutch, had lived in Bali for a long time to enjoy Balinese nature and culture. The presence of the Dutch in Bali was not only as a colonizer but they also helped promote Bali to foreign countries since Europeans and Americans began to arrive in Bali. This has had a positive impact on the progress of Balinese civilization. The increase of foreigners coming to Bali from year to year had a wide impact on the development of tourism on this island.

The development of tourism requires an increase in tourism supporting facilities. Infrastructure improvements had an impact on environmental changes in Bali, both physical and social environment. A very striking environmental change is the conversion of agricultural land into tourism supporting facilities, namely office buildings, hotels, inns, restaurants, handicraft shops, mini markets, and others. Coastal areas are the areas that have experienced the most changes. The beach which was originally used as a place to catch fish and at the same time as a place to dry the fish caught by fishermen has now changed its function as a beach tourism, such as a place for surfing, playing canoe, and a place for sunbathing while enjoying the sunrise and sunset. Ships that were originally used to catch fish are now being commercialized and used as a means of transportation for tourists to enjoy the sea view or to watch dolphins in the middle of the sea.

Besides the changes of land and area, language changes also often occur in Bali, especially in tourist destination areas. Language changes that occur are related to changes in lexicons and grammar. These changes are inseparable from changes in the natural environment and socio-cultural of the local community. On one hand, environmental changes have an impact on language change, and people's behavior towards their environment is influenced by the language they use (Fill \& Muhlhausler, 2001). The reciprocal relationship between humans and humans as well as humans and their environment results in a variety of languages, including in ecolinguistic studies. One example is the use of lexicons of nature in metaphors such as the Balinese metaphor (Rajistha, 2016), Sundanese metaphor (Suktininsih, 2016). On the other hand, the lexicons of nature are also used as people's names, such as the use of fauna and flora lexicons as names for the Miyah Ethnic (Baru, 2016). The same phenomenon is also found in Balinese language.

There are many criteria related to the environment, especially when viewed from a biological aspect, namely the environment of land, oceans, mountains, and biotic or abiotic environments. In this connection, this research only 
focuses on lexicons related to tourism, both the biotic and abiotic environment. With these considerations, the term we give to this research is ecotourism linguistic, which is a linguistic study of the tourism environment. In the previous researches, eco-lexicons can be in the form of nouns, adjectives, verbs and also in the form of noun phrases, adjective phrases, and verb phrases (Yuniawan, Rokhman, Rustono, \& Mardikantoro, 2018). The texts analyzed from an ecolinguistic point of view also have certain ideologies, such as for the Batar text which has several ideologies such as halon udan "hoping for rain" (Nahak, Simpen, Yadnya, \& Satyawati, 2019).

Sanur is one of the famous tourism areas in Bali. Sanur is the name of a village that is included in the administrative area of Denpasar. Sanur is located in the eastern part of Denpasar, the capital of Bali province. Sanur is very famous for beach tourism. The beach in this area is well-known as one of the favorite tourist destinations in Bali and is even more known before Kuta Beach. A brief history of the popularity of this area is when in 1932, an artist from Belgium named Adrean Jean Le Mayeur started sailing and stopped on the island of Bali. Then the artist married a Balinese woman named Ni Nyoman Polok. In 1937, artist A.J. Le Mayeur introduced the sunrise beach, the popular name of Sanur beach, through paintings that were exhibited abroad. Since then, the beach with calm waves and white sand has become famous to the outside community. From the history when the area was first known, it is said that Sanur with the white sand is a tourist area that was developed earlier than other areas, such as Kuta, Legian, Nusa Dua, Ubud, Lovina and others in Bali.

As one of the famous areas in Bali, even in Indonesia, Sanur has experienced many change in the past and today. The conversion of land functions in this area cannot be stopped. The conversion of agricultural land to buildings used as supporting infrastructure for tourism occurs rapidly from year to year. Changes also occur in the sociocultural aspects of the community. Changes in local Balinese language cannot be denied. In this connection, this study examines the existence of Balinese language in the area as seen from the existence of lexicons related to the biological and sociological environment of the local community. From the existence of the lexicons, it can also be seen in the change of the people's mindset in this area today and in the past.

Based on the reason, this research is very important to do considering that it can provide great benefits to scientific development, especially the study of ecolinguistics concerning to ecotourism linguistics. This research is also useful for documenting the language and culture of an area, in this case the research area of Sanur. This language documentation is important for cultural inheritance to the next generation or their posterity because with the rapidly technological development, many languages, especially many lexicons, will be possibly eroded and become archaic lexicons. Another reason is that the change in generations will automatically change customs, tradition, habits or culture. Mindset of each generation on something is always changing according to the times. Thus, the urgency of this research is also related to the importance of documenting language related to tourism development as local cultural assets that are important to be known by the next generation.

\section{Method}

Data of this research was collected through observation and interview methods along with their required techniques. Observation method was carried out to observe the signs and utterances spoken by informants in Sanur tourism area. The observation method can also be used to collect data from punctuation marks in the form of writing found in the research object area. This method requires recording and photographic techniques to store signs and speech found related to the topic analyzed in this study. Furthermore, the interview method was carried out to obtain data from informants. Interview to the informants was conducted by preparing questionnaire consisting several questions in order to collect data related to the topic of study (Djajasudarma, 1993). Interview method focuses on obtaining data in the form of information to determine the mindset, attitudes, and behavior of local people before and after the development of tourism in the area.

The collected data were then analyzed using a method of grouping based on three major groups of ecolinguistic studies. Data grouping is associated with lexicons related to the biological, sociological, and ideological environment in Sanur tourism area. In this case, it could be seen the sociological changes of the people in Sanur area today and in the past (before the tourism development in this area). In this study, it was searched whether there has been a change or shift in ideology in Sanur community after the rapid development of tourism occurred in the area.

When all the collected data were analyzed, it was found that the lexicon treasures in Sanur area is an area fully influenced by globalization, external cultural pressures, and the development of information technology. In addition, it was also found the changes of behavior and ideology of the people today compared to their behavior and ideology before the development of tourism in the area. Changes that occur in the biological, sociological, and ideological aspects are presented with the support of adequate data. The presentation of data based on the study of ecolinguistics was carried out using informal and formal methods. The informal presentation refers to the 
presentation in ordinary words, while the formal presentation refers to certain signs or symbols, such as arrows, asterisks, curly brackets, letter symbols as abbreviations, and various diagrams (Sudaryanto, 1993). With the two methods of presentation, the results of the research presented in this paper is expected to be easily understood by the readers.

\section{Results}

The results of this study indicate that there are four main activities that the people of Sanur do in their daily life (see diagram 1). These activities are related to farming, raising livestock, fishing, and tourism activities. Based on the interview results, it can be seen that $45 \%$ of the lexicon is related to farming activities. Research focusing on agricultural lexicons, such as rice fields, has been carried out by several researchers but their research locations are not in tourism area (Septevany, Dyah, Darlina, \& Rosbaedi, 2019). The results of the research conducted in Sanur tourism area indicate that the lexicons related to community activities are still known by the people of Sanur. Approximately $31 \%$ of the lexicon is related to fishing activities. This shows that the knowledge of Sanur community towards these lexicons is still quite a lot. Furthermore, about $16 \%$ of the lexicon is related to tourism activities, and $8 \%$ of the lexicon is related to livestock activities.

\section{ACTIVITY OF SANUR COMMUNITY}

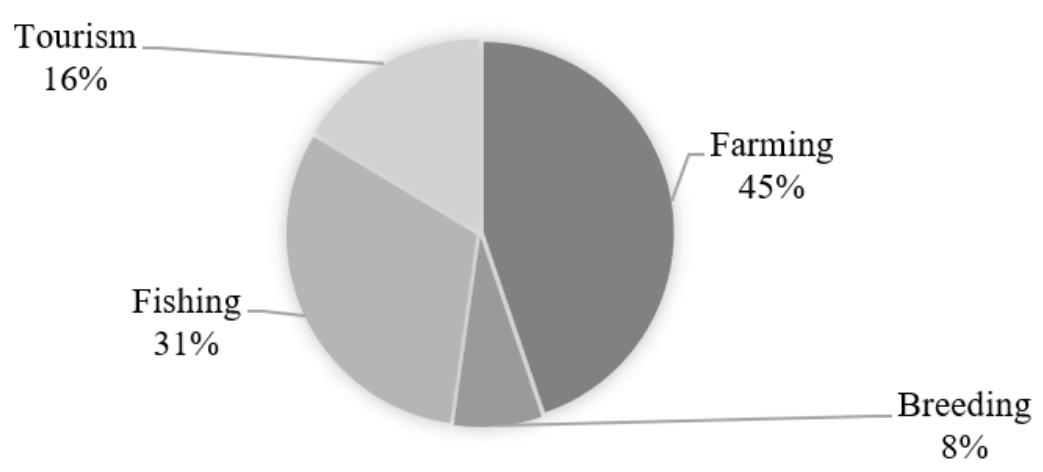

Diagram 1. Activities of Sanur community

The results of analysis further show that the lexicons are categorized as surviving lexicons and are still widely by the people of Sanur. However, in this case, the lexicons are classified into three categories, namely (1) lexicons of which activities are not found anymore today, (2) lexicons of which several activities are still found today, and (3) lexicons of which many activities are still found today. About $12 \%$ of the lexicon known by the people of Sanur do not have any physical form and activities today as they are no longer practiced by the people. However, about $51 \%$ of the lexicon known by the people in Sanur still have physical forms or activities and they are in small quantity or rare intensity. Finally, about $37 \%$ of the lexicon is still used with frequent intensity and large quantities. For more details, see diagram 2 .

\section{LEXICON CONDITION}

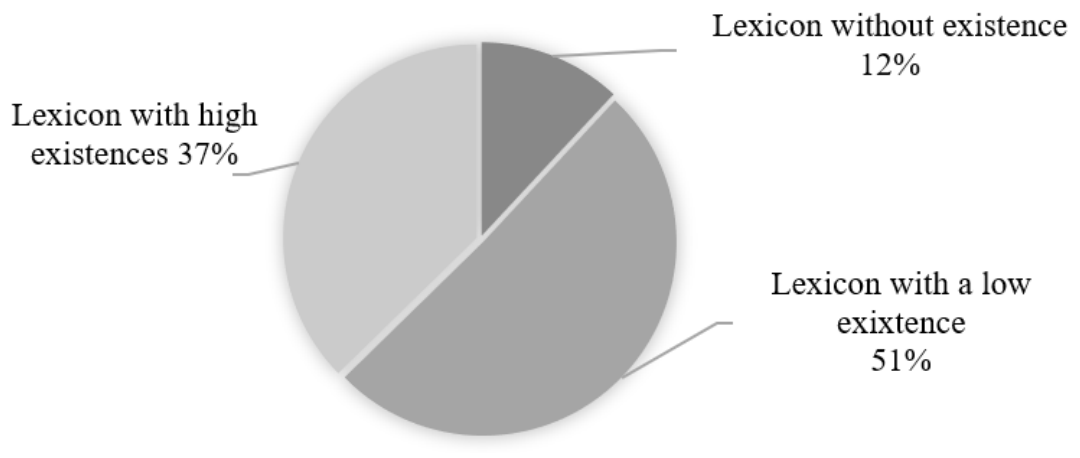

Diagram 2. Lexicon condition in Sanur area 
Sanur community can be said to be very open in accepting new concepts / terms related to all the activities they do. Based on the interview, it can be seen that the people of Sanur today use concepts/terms in Balinese language as much as $76 \%$ and the remaining $24 \%$ in English and Indonesian language. In this case, it is meaning that English and Indonesian language have quite influential in the lexicons of Sanur community. Diagram 3 below shows the conditions of concepts/terms mastered by Sanur community both in Balinese and in English or in Indonesian language

\section{CONCEPT/TERM CONDITION}

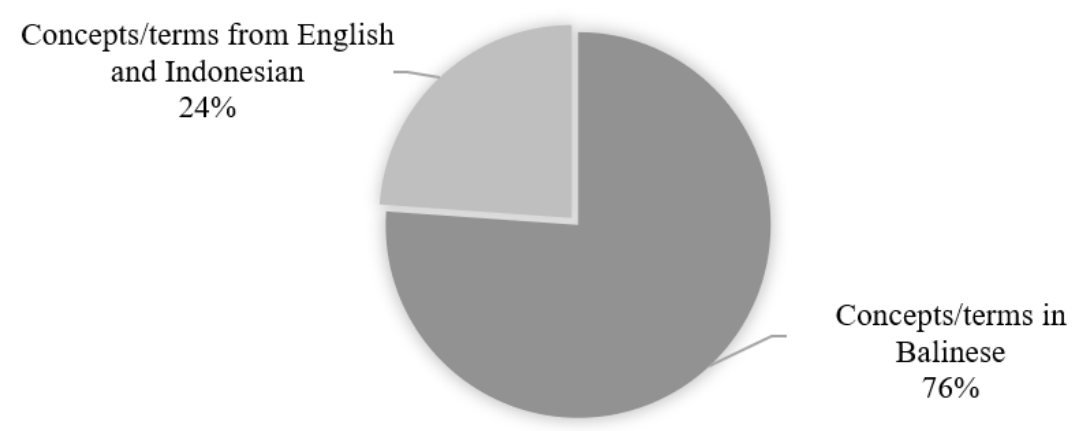

Diagram 3. Concept/term condition in Sanur area

Furthermore, based on the interview, it can be seen that about $27 \%$ of the lexicon used by Sanur community was obtained after tourism had developed in the area (see diagram 4). This proves that the development of tourism in Sanur does not only affect the socio-economic conditions of the community but also affects their language. In this case, the concept of language and power is implemented in their daily life. English as the international language has slowly eliminated and dominated several Balinese lexicons, especially in tourism areas where global transactions and communications often occur.

\section{USE OF LEXICON}

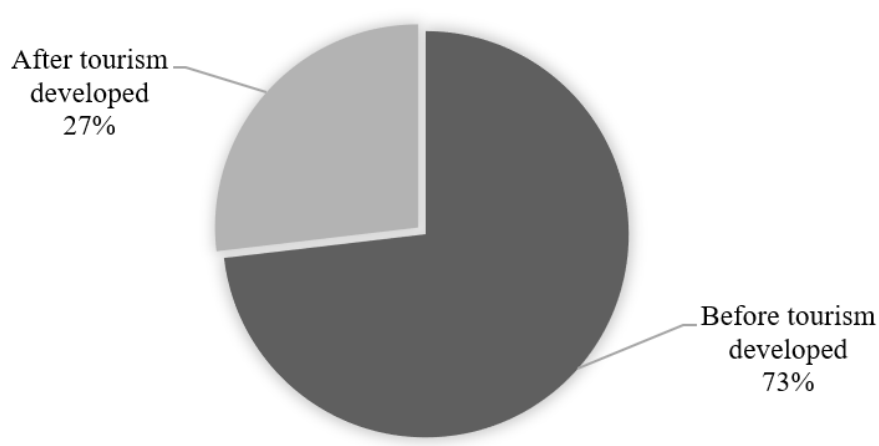

Diagram 4. The use of lexicon by Sanur community

The latest results from the interviews show the use of lexicons of English and Indonesian language in the following activities (see diagram 5). Based on diagram 5, it can be seen that the percentage of the new lexicons into fishing and tourism activities are the same, namely as much as $47 \%$. Meanwhile, the new lexicons related to farming activities is about $6 \%$, and no new lexicons are found related to livestock activities. This shows that activities related to farming and livestock are not widely carried out internationally. 


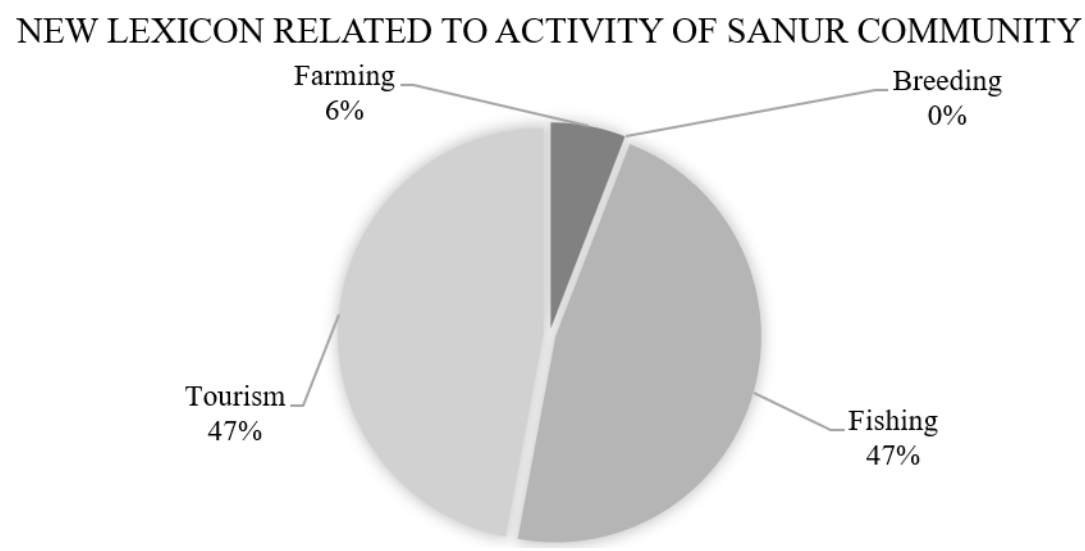

Diagram 5. New lexicon related to activity of Sanur community

\section{Discussion}

Environmental changes in the tourism area of Sanur generally have a very big impact on the profession that is engaged in by the community. The next impact is related to the use of language by the local community. There are certain concepts or terms owned by society that can survive up to today because these concepts are frequently used by the speakers or the community. However, some concepts/terms that are rarely used by the community because the activities they refer to are not often done anymore. This condition has forced the lexicons become unfamiliar and even unknown by the speakers of the next generation. This could cause the concepts/terms to disappear and become extinct from a culture

Based on the data collected, the lexicons mastered and used by the people of Sanur are very much influenced by their daily activities in accordance with the profession that the Sanur community is engaged in. So, the lexicon used by the community is closely related to people's daily activities. For the reason, the lexicons used today are not only in the form of concepts/terms existed before the tourism developed in the area but also new concepts which are absorbed from foreign languages due to the very rapid development of tourism. Until now, there are several professions that the people of Sanur have been engaged in, namely farmers, breeders, fishermen, and workers in tourism sector.

In the farming sector, the people of Sanur are still familiar with concepts related to agricultural activities. However, not all the lexicons related to agricultural activities still exist today. There are some lexicons only existing in the form of concepts but their objects/activities are not found anymore and even the concept of the lexicons are known only by the people who have experienced, seen, or engaged in the activities stated by the lexicons. This is in line with the opinion which states that language treasures related to the created form of eco-lexicon wealth cannot be separated from the environment in which the language lives (Tualaka, 2016). Furthermore, Genua states that semantically the external referential meaning of the lexicon of the Nagekeo ethnic food plants lives and develops in the community (Genua, 2016). Other studies have shown that the environmental changes cause the changes in the existing natural lexicon, such as the use of flora as one of the traditional foodstuffs which is slowly being replaced by the use of other flora, then the initial flora used will begin to be forgotten. This causes a shift in language (Tarigan, Setia, Widayati, \& Mbete, 2016). Searching the conditions in the Sanur area, several agricultural lexicons still survive because farming activities are still carried out even though their intensity is much lower than the times before the tourism developed in this area. The following are lexicons related to farming activities whose concept still persists even though the existence of the activity or object as the referent for these lexicons is not available as before the development of tourism in Sanur area. 
Table 1. Lexicon related to Farming Activity

\begin{tabular}{|c|c|c|c|c|c|c|c|}
\hline \multirow[b]{2}{*}{ No. } & \multirow[b]{2}{*}{ Lexicon } & \multirow{2}{*}{$\begin{array}{l}\text { Related } \\
\text { to } \\
\text { activity }\end{array}$} & \multirow{2}{*}{$\begin{array}{l}\text { Existence } \\
\text { related to } \\
\text { tourism }\end{array}$} & \multicolumn{2}{|l|}{ Form } & \multirow[b]{2}{*}{ Condition } & \multirow[b]{2}{*}{ Quantity/Intensity } \\
\hline & & & & Activity & Referent & & \\
\hline 1. & abian (ladang) & Farming & Before & & $\sqrt{ }$ & Exist & - \\
\hline 2. & Punyan nyuh & Farming & Before & & $\sqrt{ }$ & Exist & - \\
\hline 3. & Busung & Farming & Before & & $\sqrt{ }$ & Exist & - \\
\hline 4. & mederep & Farming & Before & $\sqrt{ }$ & & $\mathrm{X}$ & $\mathrm{x}$ \\
\hline 5. & seseh & Farming & Before & & $\sqrt{ }$ & Exist & - \\
\hline 6. & ngelesung & Farming & Before & $\sqrt{ }$ & & X & $\mathrm{x}$ \\
\hline 7. & majeg & Farming & Before & $\sqrt{ }$ & & Exist & - \\
\hline 8. & Punyan boni & Farming & Before & & $\sqrt{ }$ & Exist & - \\
\hline 9. & Punyan juwet & Farming & Before & & $\sqrt{ }$ & Exist & - \\
\hline 10. & Punyan biu & Farming & Before & & $\sqrt{ }$ & Exist & - \\
\hline 11. & Punyan tiing & Farming & Before & & $\sqrt{ }$ & Exist & - \\
\hline 12. & carik & Farming & Before & & $\sqrt{ }$ & Exist & - \\
\hline 13. & Poh nerasa & Farming & Before & & $\sqrt{ }$ & Exist & - \\
\hline 14. & Danguk & Farming & Before & & $\sqrt{ }$ & Exist & + \\
\hline 15. & Ngarit & Farming & Before & $\sqrt{ }$ & & Exist & - \\
\hline 16. & Numbeg & Farming & Before & $\sqrt{ }$ & & Exist & - \\
\hline 17. & Perit & Farming & Before & & $\sqrt{ }$ & Exist & - \\
\hline 18. & lipi & Farming & Before & & $\sqrt{ }$ & Exist & - \\
\hline 19. & Alu & Farming & Before & & $\sqrt{ }$ & Exist & - \\
\hline 20. & Keong mas & Farming & Before & & $\sqrt{ }$ & Exist & - \\
\hline 21. & mebakin & Farming & Before & $\sqrt{ }$ & & X & $\mathrm{x}$ \\
\hline 22. & petakut & Farming & Before & & $\sqrt{ }$ & Exist & - \\
\hline 23. & kiling & Farming & After & & $\sqrt{ }$ & Exist & - \\
\hline 24. & metekap & Farming & Before & $\sqrt{ }$ & & X & $\mathrm{x}$ \\
\hline 25. & nenggala & Farming & Before & $\sqrt{ }$ & & $\mathrm{X}$ & $\mathrm{x}$ \\
\hline
\end{tabular}

Descripstion:

- $\quad$ : a few/rarely

$+\quad:$ many/frequently

$\mathrm{x} \quad$ : not available

Based on the table above, several lexicons such as ngampig 'separating rice grains', maderep 'cutting and tying rice', ngelesung 'pounding rice using a mortar', and mabakin 'opening fields' are lexicons related to agricultural activities that are currently never carried out anymore because of the availability of technological tools used to do these activities. Today these lexicons still survive and are known only by people who have experienced and carried out these activities in the past. However, these activities only survive in the form of concepts and the real activities of the lexicons are no longer found. Again, this is due to the advances in technology. Activities that were carried out traditionally in the past are now replaced by more sophisticated tools resulting from technological advances and can increase the speed and the quality of work. Other lexicons that do not exist today are matekap and nenggala which relate to plowing the fields before they are ready to plant rice. This activity was previously carried out by humans and assisted by a pair of adult cows. However, thanks to technological advances, these activities are currently carried out with tractors and these tools can facilitate and accelerate the cultivation of agricultural land by the community. Another lexicon related to rice fields is the word petakut, 'a means of repelling birds for rice pests when rice plants are bearing fruit'. However, the word petakut has now been replaced by the word kiling which has the same function as petakut. The word kiling was adopted from the English lexicon of killing. The meaning of the word kiling is expelling or making the birds go away and it is associated with the same meaning as the word killing in English. Although most of the lexicon on concepts related to agricultural activities still survive and are still used by the people of Sanur, the quantity and intensity of their use have decreased or become very rarely. This is because the land has been converted into tourism support facilities, such as roads and buildings, namely hotels, restaurants, art shops, offices, malls, and others. 
In addition to lexicons related to farming activities, other lexicons whose concept is still well known by the people of Sanur are lexicons related to raise livestock activities. The lexicons can be seen in the following table.

Table 2. Lexicon related to raise livestock activities

\begin{tabular}{|c|c|c|c|c|c|c|c|}
\hline \multirow[b]{2}{*}{ No. } & \multirow[b]{2}{*}{ Lexicon } & \multirow[b]{2}{*}{$\begin{array}{l}\text { Related to } \\
\text { activity }\end{array}$} & \multirow{2}{*}{$\begin{array}{l}\text { Existence } \\
\text { related } \\
\text { to } \\
\text { tourism }\end{array}$} & \multicolumn{2}{|l|}{ Form } & \multirow[b]{2}{*}{ Condition } & \multirow[b]{2}{*}{ Quantity/intensity } \\
\hline & & & & Activity & Referent & & \\
\hline 1 & kucit & raise livestock & Before & & $\sqrt{ }$ & Exist & - \\
\hline 2 & siap & raise livestock & Before & & $\sqrt{ }$ & Exist & - \\
\hline 3 & Tebe-tebe & raise livestock & Before & & $\sqrt{ }$ & $\mathrm{X}$ & $\mathrm{x}$ \\
\hline 4 & gedebong & raise livestock & Before & & $\sqrt{ }$ & Exist & - \\
\hline 5 & sengauk & raise livestock & Before & & $\sqrt{ }$ & Exist & - \\
\hline \multicolumn{8}{|c|}{ Description: } \\
\hline \multicolumn{8}{|c|}{ - : a few/rarely } \\
\hline \multicolumn{8}{|c|}{$+\quad$ : many /frequently } \\
\hline $\mathrm{x} \quad$ : & not availabl & & & & & & \\
\hline
\end{tabular}

The table above shows that raise livestock activities are less than farming activities. It is found that initially raising livestock activities were carried out in each household in tebe 'backyard' area. However, since the development of tourism in Sanur, most of the people of Sanur have started to follow the developments and advancements of tourism in the area. The activities of raising livestock in the home environment were slowly abandoned. In this case, tebe 'backyard' is currently used as much as possible to support tourism facilities, such as restaurants, cafes, coffee shops, mini markets, art shops, and others. Before tourism developed, tebe was used to raise siap 'chickens' and kucit 'pig'. In raising chickens, it's not like now, they are left free and wild in the yard. However, if there is now a family that still raises pigs or chickens, the breeding system and the quality and types of the pigs and chickens are adjusted to the needs of tourism.

Based on the research, there are also lexicons related to fishing activities. These lexicons are conceptually existing lexicons before and after tourism developed in the area. Tourism development greatly affects the activities of the people of Sanur who work as fishermen, especially in terms of their language. Environmental changes occur due to the need to support tourism. The environment does not only change fishermen's habits but also provides new concepts that are absorbed from English. These concepts continue to survive and even the old ones are starting to be abandoned or have been rarely used by the community. For more details, consider the following table.

Tabel 3. Lexicon Related to Fishing Activities

\begin{tabular}{|c|c|c|c|c|c|c|c|c|}
\hline \multirow[b]{2}{*}{ No. } & \multirow[b]{2}{*}{ Lexicon } & \multirow{2}{*}{$\begin{array}{l}\text { Related to } \\
\text { activity }\end{array}$} & \multirow{2}{*}{$\begin{array}{l}\text { Existence } \\
\text { related } \\
\text { tourism }\end{array}$} & \multirow[b]{2}{*}{ to } & \multicolumn{2}{|l|}{ Form } & \multirow[b]{2}{*}{ condition } & \multirow[b]{2}{*}{ Quantity/Intensity } \\
\hline & & & & & Activity & Referent & & \\
\hline 1. & joran & Fishing & Before & & & $\sqrt{ }$ & Exist & + \\
\hline 2. & mangsuk & Fishing & Before & & $\sqrt{ }$ & & Exist & - \\
\hline 3. & balangtudu & Fishing & Before & & & $\sqrt{ }$ & Exist & - \\
\hline 4. & snorkel & Fishing & After & & $\sqrt{ }$ & & Exist & + \\
\hline 5. & ngeter & Fishing & Before & & $\sqrt{ }$ & & Exist & - \\
\hline 6. & mubu & Fishing & Before & & $\sqrt{ }$ & & Exist & - \\
\hline 7. & Ulad-ulad & Fishing & Before & & & $\sqrt{ }$ & Exist & + \\
\hline 8. & $\begin{array}{l}\text { Paluh- } \\
\text { paluh }\end{array}$ & Fishing & Before & & & $\sqrt{ }$ & Exist & + \\
\hline 9. & trap & Fishing & After & & & $\sqrt{ }$ & Exist & + \\
\hline 10. & nyeser & Fishing & Before & & $\sqrt{ }$ & & Exist & + \\
\hline 11. & handline & Fishing & After & & $\sqrt{ }$ & & Exist & + \\
\hline 12. & ril & Fishing & After & & & $\sqrt{ }$ & Exist & + \\
\hline 13. & ngugang & Fishing & Before & & $\sqrt{ }$ & & Exist & - \\
\hline
\end{tabular}




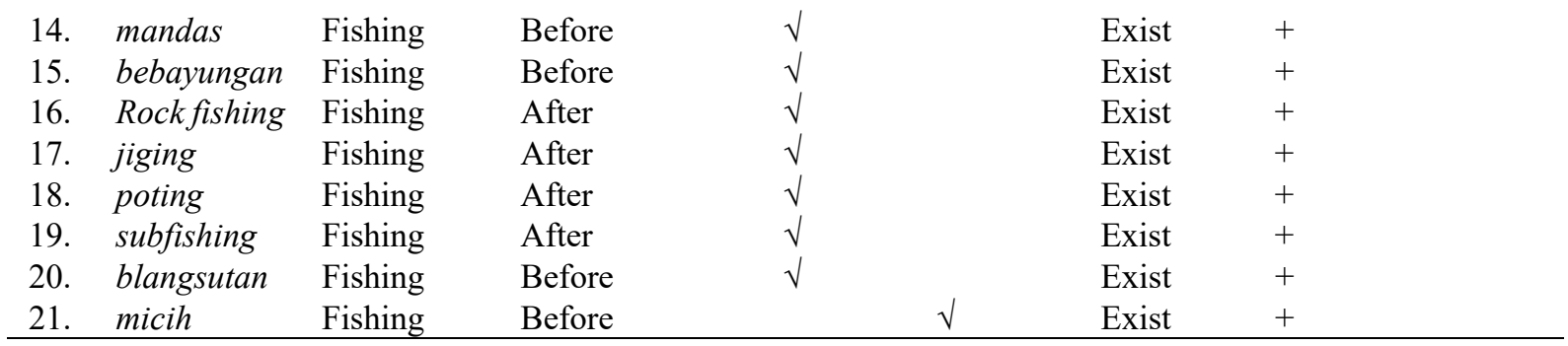

Description:

- $\quad$ : A few/rarely

$+\quad:$ many /frequently

$\mathrm{x} \quad$ : not available

The table above shows that fishing activities are still familiar to the people of Sanur. However, most of the activities the people do today related to fishing are not like what they used to do in the past, and even some of the fishing activities done today are used to support tourism needs. The concepts used also absorb and adopt some concepts from English language. This happens because of the direct and indirect interaction between foreigners using English and the people of Sanur. Direct interaction occurs because some fishermen also work in tourism sector to give services to foreigners, while indirect interactions occur because the fishing community interacts with other fishing communities who are also involved in tourism sector. In this case, English is slowly entering the life of the fishing community as a result of the development of tourism in Sanur area

Furthermore, gradually the lexicons used by the people of Sanur began to follow the development of tourism. In regarding with industry and tourism, batik is one of the handicrafts which is also very close to nature (Yuniawan, Rokhman, \& Zulaeha, 2020). In Bali, the typical hand-made cloth of Balinese people called endek is also very popular in Bali and beyond. This endek cloth is widespread in tourism areas including Sanur area. In each art shop, various styles of endek clothes for men and women could be found.

The following table shows the lexicons related to tourism. From this table, it is known that almost no words (concepts) have managed to survive because of tourism pressure. For example, the Balinese word kraca 'small shells' which was previously collected by the community around the beach that was used to make accessories, is now conceptually still surviving, but there are not any objects and community activities referred to this word. Likewise, a number of words or other lexicons are almost extinct because their objects and activities are no longer found. However, there is one lexicon that has survived until now and even its existence has increased. The lexicon is the word babi guling 'sparkling pig'. The word babi guling is one of Balinese specialties that has a special taste. This kind of food has become one of the most famous foods and it is very popular to local people and to domestic and foreign tourists as well. Therefore, the quantity or intensity of the use of the lexicon in tourism sector is also very frequent. This is because many people of Sanur choose to work in the tourism sector because the tourism sector provides opportunities and is very promising financially.

Table 4. Lexicon related to Tourims Activity

\begin{tabular}{|c|c|c|c|c|c|c|c|c|}
\hline \multirow{2}{*}{ No. } & \multirow{2}{*}{ Lexicon } & \multirow{2}{*}{$\begin{array}{l}\text { Related } \\
\text { Activity }\end{array}$} & \multirow[t]{2}{*}{ to } & \multirow{2}{*}{$\begin{array}{l}\text { Existence related } \\
\text { to Tourism }\end{array}$} & \multicolumn{2}{|l|}{ Form } & \multirow{2}{*}{ Condition } & \multirow{2}{*}{$\begin{array}{l}\text { Quantity/ } \\
\text { Intensity }\end{array}$} \\
\hline & & & & & Activity & Referent & & \\
\hline 1. & kraca & Tourism & & Before & & $\sqrt{ }$ & $\mathrm{X}$ & $\mathrm{x}$ \\
\hline 2. & $\begin{array}{l}\text { Nelayan } \\
\text { pariwisata }\end{array}$ & Tourism & & After & & $\sqrt{ }$ & Exist & + \\
\hline 3. & order & Tourism & & After & $\sqrt{ }$ & & Exist & + \\
\hline 4. & travel & Tourism & & After & $\sqrt{ }$ & & Exist & + \\
\hline 5. & slip & Tourism & & After & & $\sqrt{ }$ & Exist & + \\
\hline 6. & Babi guling & Tourism & & Before & & $\sqrt{ }$ & Exist & + \\
\hline 7. & gowes & Tourism & & After & $\sqrt{ }$ & & Exist & + \\
\hline 8. & Bule & Tourism & & After & & $\sqrt{ }$ & Exist & + \\
\hline 9. & Sailing boat & Tourism & & After & & $\sqrt{ }$ & Exist & + \\
\hline 10. & diving & Tourism & & After & $\sqrt{ }$ & & Exist & + \\
\hline 11. & Jogging track & Tourism & & After & & $\sqrt{ }$ & Exist & - \\
\hline
\end{tabular}




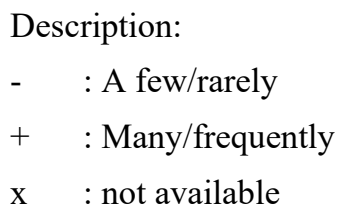

Based on those tables, it could be seen that Balinese language that survives can be in the form of (1) lexicons that still have a concept but the existence of objects or activities of the concepts no longer exist, and (2) words whose concepts, objects, and activities still exist. There are two basic things that cause language change in the Sanur area, namely a change in land use and a change in the community's profession due to the impact of tourism development in the area. The impact of tourism development also affects the level of community welfare. This is inversely to language maintenance. The concepts realized by the lexicon relating to traditional technology and people's lives before tourism developed in the area are slowly being forgotten. This of course will affect the number of vocabulary in Balinese. Maybe in the future, only a small proportion of Balinese vocabulary will exist especially in tourism areas in Bali.

Furthermore, this research explores: What is the perception of Sanur community towards tourism development? Which is better, before or after tourism developed in the area? Based on the analysis, it could be concluded that there are three periods of change in the pattern of people's lives. The first period is the period before tourism developed. During this period, the people still lived simply and the condition of the nature of Sanur such as rice field, beach, and sea were still beautiful. At this time the concepts/language related to the life activities of the people of Sanur were still found. The second period is the time after tourism was introduced to the people of Sanur. At that time Sanur became a very famous tourism area in Bali and Indonesia. During this period, the life of the people of Sanur began to change and led to changes that support tourism needs. They thought that this period is the best period for the people of Sanur. At this time, it is believed that the language used by the new community was influenced by English, but the concepts / terms related to the period before tourism developed were still fully understood. And then, the third period is the period in which Bali has become a major and well-known tourist destination in Indonesia and the world. During this period, many areas in Bali developed into famous tourist destinations. The number of developing tourism areas in Bai has influenced the development of tourism in Sanur. In this period, the progress of tourism in Sanur is going flat, unlike the progress in the second period. Thus, the second period is called the golden period for the development of Sanur area.

In this second period (also called the golden period), tourists have begun to develop and the nature of Sanur still maintained and looks so natural and beautiful. Massive development of tourism in Bali has not been carried out yet at this period. People were still easy to find daily needs and they could make their lives prosperous through activities in the tourism sector. In this period Balinese language was in a transitional period, the influence of English into Balinese language has occurred due to the development of tourism. Lexicons related to the biotic and abiotic environment were still widely used. This is in accordance with the theory that states that language becomes exist because of the existence of objects or activities carried out by society. When the existence of objects and activities does not exist, then slowly the concept of objects and activities is forgotten until a generation of these concepts is completely lost. This happens to Balinese language in Sanur area.

\section{Conclusion}

Based on the results of the analysis, it could be concluded that lexicons related to the activities of the Sanur community can be classified into lexicons related to farming, livestock, fishing and tourism activities. These lexicons are not only lexicons that have a physical form or an activity, but some lexicons now exist only in concepts without any objects or activities referred to are found in Sanur area. In this case, environment must be the concern of all parties. There are many ways to increase awareness of the environment, for the sake of language sustainability, one of which is through children's stories (Ramadan, 2020), advertisements, and other texts that are widely disseminated (Bailo et al., 2019).

The perception of Sanur community towards the language change can be categorized into before and after the tourisn developed in the area. At the period before tourism developed massively in Bali, people still felt the balance between nature and tourism. At this time there were still many lexicons that had an existence in the form of objects and community activities found in Sanur. This is different from the period after tourism developed massively in Bali. All things are used to support tourism. The people focused on the development of tourism that promises prosperity for their lives. Flora, fauna, and community activities that do not support tourism are neglected so that what happens today is scarcity, extinction, and loss of certain activities that affect language extinction. 


\section{Acknowledgements}

This research was supported by a grant from Warmadewa University. Thus, in this occasion I would like to thank Rector of Warmadewa University for the annual grant provided to lecturers who are interested in conducting researches related to tourism and culture. I am also grateful to all informants living in Sanur area for their willingness to give expected data for this study. Special thanks are also delivered to my colleagues at Faculty of Letters for their contribution to complete this study.

\section{References}

Bailo, V. B., Tonon, C., Paesani, L., Sidari, G., Zanin, V., Boldi, S., \& Capovilla, E. (2019). Shaping self: Ecolinguistic studies of identity. Language \& Ecology.

Baru, Y. (2016). Leksikon nama orang pada Etnis Miyah: Kajian ekolinguistik. Kibas Cenderawasih, 13(1), 4350.

Fill, A., \& Muhlhausler, P. (2001). The Ecolinguistics Reader: Language, Ecology and Environment. London: Continum.

Genua, V. (2016). Khazanah Leksikon Tanaman Pangan Etnik Nagakeo : Kajian Ekolinguistik. In Simposium Internasional Bahasa-Bahasa Lokal, Nasional dan Global.

Nahak, M. M. N., Simpen, I. W., Yadnya, I. B. P., \& Satyawati, N. M. S. (2019). Lexicon in Batar Text: Ecolinguistics View. International Journal of Linguistics, Literature and Culture, 5(6), 48-59. https://doi.org/10.21744/ijllc.v5n6.763

Rajistha, I. G. N. A. (2016). Beblabadan Bahasa Bali dalam Perspektif Ekolinguistik. RETORIKA: Jurnal Ilmu Bahasa, 2(1), 79-94. https://doi.org/10.22225/jr.2.1.223.79-94

Ramadan, D. A. (2020). Disappearance of the Nile: Storytelling and environmental awareness. Language \& Ecology.

Septevany, E., Dyah, W., Darlina, L., \& Rosbaedi. (2019). Khazanah Leksikon Kepadian Sawah Komunitas Tutur Sunda: Kajian Ekolinguistik. Seminar Riset Linguistik Pengajaran Bahasa, 3, 8-17.

Sudaryanto. (1993). Metode dan Teknik Analisis Bahasa. Yogyakarta: Duta Wacana University Press.

Suktiningsih, W. (2016). Leksikon Fauna Masyarakat Sunda: Kajian Ekolinguistik. RETORIKA: Jurnal Ilmu Bahasa, 2(1), 142-160. https://doi.org/10.22225/jr.2.1.54.142-160

Tarigan, B., Setia, E., Widayati, D., \& Mbete, A. M. (2016). Language Maintenance and Shift of Flora's Lexicons in Karonese Traditional Food: An Ecolinguistic Perspective. Communication and Linguistics Studies, 2(1), 13-17.

Tualaka, D. (2016). Bentuk Khazanah Ekoleksikon Pertanian Bahasa Waijewa. MELANESIA: Jurnal Ilmiah Kajian Sastra Dan Bahasa, 1(1), 105-113. https://doi.org/10.30862/jm.v1i1.742

Yuniawan, T., Rokhman, F., \& Zulaeha, I. (2020). Eco-linguistic Analysis on Flora and Fauna Lexicons on the Motifs of Batik Pekalongan, Indonesia. International Journal of Advanced Science and Technology, 29(5), 6549-6566.

Yuniawan, T., Rokhman, F., Rustono, \& Mardikantoro, H. B. (2018). Eco-Lexicons in Conservation News Text in Mass Media: Ecolinguistics Study. The Journal of Educational Development, 6(1), 1-15.

\section{Copyrights}

Copyright for this article is retained by the author(s), with first publication rights granted to the journal.

This is an open-access article distributed under the terms and conditions of the Creative Commons Attribution license (http://creativecommons.org/licenses/by/4.0/). 